between serum albumin and serum zinc in 27 patients with leprosy, and no difference between mean serum albumin values in two groups of leprosy patients with high and low serum zinc concentrations. On the other hand, the serum zinc concentrations were also decreased in patients receiving dapsone for dermatitis herpetiformis. All the leprosy patients were receiving dapsone, and though the protein fractions involved in zinc and dapsone binding are unknown (Prasad and Oberleas, 1970; Weinstein, 1970) competition by dapsone for zinc binding sites on plasma proteins cannot be excluded.

Impaired plasma protein binding is only one of several possible explanations for lowered serum zinc concentrations in leprosy. Experimental evidence suggests that toxaemia of chronic infection causes lowering of the serum zinc, probably as a result of a redistribution of zinc from serum to cells (Pekarek and Beisel, 1969). Toxaemia is not a feature of leprosy and serum zinc concentrations were not dependent on the tissue population of $M$. leprae as reflected in the results of smear examinations. Bacterial toxaemia could, however, be the explanation for the striking findings in pulmonary tuberculosis, in which low serum zinc concentrations coexisted with high skin concentrations. Halstead and Smith (1970) found noticeably lowered serum zinc concentrations in patients with aotive pulmonary tuberculosis and our findings were similar. Dietary factors may cause a decrease of serum zinc (Rheinold et al., 1973) but are unlikely to have been important in our patients, who were all receiving nutritionally adequate hospital diets.

Though these mechanisms may to varying degrees influence the serum zinc concentration in leprosy the most likely explanation for the decreased serum values is that they are a non-specific metabolic consequence of skin disease, since a similar lowering of serum or plasma zinc concentrations was found in pulmonary tuberculosis in the present study and in psoriasis, venous leg ulceration, and other dermatoses in an earlier investigation (Greaves and Boyde, 1967). Shuster and Marks (1970) highlighted the varied metabolic costs of skin disease, which include lowering of the serum iron, folate deficiency, and hypoalbuminaemia, and it seems probable that lowered serum zinc should be added to the list. The presumed non-specific nature of the decreased serum zinc in trophic skin ulceration of leprosy does not, however, exclude the possibility that zinc may be a limiting factor in the rate of healing of the ulcers, and it is of interest that in leg ulceration from other causes also associated with decreased serum zinc concentrations a beneficial effeot of systemic zinc treatment has been claimed (Husain, 1969; Serjeant et al., 1970; Hallbook and Lanner, 1972).

This work was supported by a grant from the Nuffield Foundation to $\mathrm{M}$. W. Greaves. Other financial aid was provided by $\mathrm{Mr}$. R. J. Hulse, Medo-Chemicals Ltd., London. We are also grateful to the Director of Medical Services, Ministry of Health, Singapore; Dr. V. S. Rajan, Middle Road Hospital; and Dr. Ng Yook Kim, Tan Tock -Seng Hospital, for providing facilities. We thank Professor Sam Shuster for helpful comments. Miss Maureen Davison, Mr. Ng Bee Tong, and Mr. Jim Gossop gave excellent technical help.

\section{References}

Caughey, J. E. (1973). Lancet, 2, 376.

Documenta Geigy (1970). Scientific Tables, 7th edn., p. 553. Macclesfield, Geigy (U.K.) Pharmaceuticals.

Greaves, M. W., and Boyde, T. R. C. (1967). Lancet, 2, 1019.

Hallbook, T., and Lanner, E. (1972). Lancet, 2, 780.

Halstead, J. A., and Smith, J. C. (1970). Lancet, 1, 322.

Harrison, W. W., Netsky, M. G., and Brown, M. D. (1968). Clinica Chimica Acta, 21, 55

Husain, S. L. (1969). Lancet, 1, 1069.

Molokhia, M. M., and Portnoy, B. (1969). British fournal of Dermatology, 81, 759 .

Pekarek, R. S., and Beisel, W. R. (1969). Applied Microbiology, 18, 482.

Pekarek, R. S., Beisel, W. R., Bartelloni, P. J., and Bostian, K. A. (1972).

American fournal of Clinical Pathology, 57,506 .
Pories, W. J., and Strain, W. H. (1970). In Trace Element Metabolism in Animals, ed. C. F. Mills, p. 75 . Edinburgh, Livingstone.
A

Animals, ed. C. F. Mils, p. 75. Edinburgh, Livingstone.
Prasad, A. S., and Oberleas, D. (1970). Fournal of Laboratory and Clinical Medicine, 76, 416.

Rheinold, F. G., Nasr, K., Lahimgarzadeh, A., and Hedayati, H. (1973). Lancet, 1, 283.

Serjeant, G. R., Galloway, R. E., and Gueri, M. C. (1970). Lancet, 2, 891.

Shuster, S. (1967). Lancet, 1, 907.

Shuster, S., and Bottoms, Eva (1963). Clinical Science, 25, 487.

Shuster, S., and Marks, Janet (1970). Systemic Effects of Skin Disease. London, Heinemann.

Shuster, S., Raffle, E. J., and Bottoms, Eva (1967). Lancet, 1, 525.

Strain, W. H., and Pories, W. J. (1966). In Zinc Metabolism, ed. A. S. Prasad,

p. 363. Springfield, Thomas.
Weinstein, L. (1970). In The Pharmacological Basis of Therapeutics, ed. L. S. Goodman and A. Gilman, 4th edn., p. 1311. London, Macmillan

Withers, A. F. D., Baker, H., Musa, M., and Dormandy, T. L. (1968). Lancet, 2, 278 .

\title{
Eye Defects of Mentally Handicapped Children
}

\author{
J. L. KENNERLEY BANKES
}

British Medical fournal, 1974, 2, 533-535

\section{Summary}

Among 171 children who received routine ophthalmic and orthoptic examinations as part of their evaluation for suspected or known developmental handicap it was found that there was an unusually high incidence of ocular defects. Especially prevalent were high refractive errors $(52 \%)$ and squints $(40 \%)$, but there were also a number of other serious eye defects ranging from nystagmus and cataracts to microphthalmos.

Because of this high incidence of eye defects it was considered essential that ophthalmic and orthoptic

St. Mary's Hospital, London W2 1NY

J. L. KENNERLEY BANKES, D.o., F.R.C.S., Consultant Ophthalmic Surgeon examinations should be part of the routine evaluation of developmentally handicapped children by the team of workers in an assessment centre.

\section{Assessment Centre}

Routine ophthalmic examination of known or suspected mentally handicapped children is still very far from being standard practice. The purpose of this paper is to emphasize the need for full ophthalmic and orthoptic evaluation of mentally handicapped children as part of the routine examination of an assessment centre team. Such an assessment centre team of workers has been working together for some four years at St. Mary's Hospital, London, in the children's department. The team consists of the following members: a consultant paediatrician, another paediatrician, who is also principal medical officer for Westminster City Council, a consultant ophthalmic surgeon, an audiologist, who is a senior registrar, an orthoptist, an audio- 
metrist, and a medical social worker. Each member of the team has special experience in his particular examination and evaluation methods as standard examination methods may need modifying when considering the needs of mentally handicapped children.

The children attending the assessment centre were referred from general practitioners, local authority medical officers, and other medical specialists mainly because of suspected or established slow development. Some children were referred, however, because of a known mental or associated physical handicap such as mongolism or cerebral palsy, but by far the majority of the children were referred because of delay in reaching the milestones of childhood $(64 \%)$.

\section{Assessment}

The working routine for the assessment centre was carried out in the following way. Each child had a full physical examination by one paediatrician, and when indicated further laboratory tests and $x$-ray examinations were carried out. Usually, however, laboratory tests had been carried out by the referring doctor. The second paediatrician, who was also a medical officer of the Westminster City Council, then carried out the developmental tests using the Griffiths Mental Developmental Scale (Griffiths, 1954). After this full ophthalmic examination was carried out by the consultant ophthalmic surgeon including direct and indirect ophthalmoscopy, cycloplegic retinoscopy, and, when practicable, slit-lamp microscopy. The orthoptist then enlarged on this examination by doing a detailed orthoptic evaluation on each child.

Routine ear, nose, and throat examinations and audiometry test were carried out to complete the assessment. It was not always possible or desirable to complete the full assessment in one session so the number of attendances at the centre of each child varied.

When the assessment information for each child was correlated, and the medical social worker had seen the parents or guardian, discussion took place as to the future care and management of each child. Where specific treatment was neededfor example, for cataracts or a squint-then this could be coordinated with the other aspects of management. Hence it was possible to provide specific treatment within the framework of the assessment team and not in isolation as is usually the case.

\section{Ocular Findings in 171 Children}

The general presenting features of 171 children are listed in table I. Altogether 110 children (64\%) presented with delayed development alone, while only relatively few children had physical abnormalities drawing attention initially to their developmental handicap (mongolism 12\%, cerebral palsy $10 \%$, and hydrocephalus $5 \%$ ). The age range of the children varied between five months and 10 years with 16 of the children being less than 1 year, 100 children being between 1 and 5 years, and 55 children being between 5 and 10 years of age. The average age was 4 years 2 months.

The ocular findings are summarized in table II. There were only $39(23 \%)$ out of the 171 children who could be considered ophthalmically normal without refractive error or other ocular abnormality. The major defects were significant refractive errors (more than 1.50 dioptres of hypermetropia, more than 0.75 dioptre of myopia, and more than 0.75 dioptre of astigmatism), and often spectacles were needed to correct these errors, especially when they were associated with squints.
Squints were present in 69 children $(40 \%)$, all but one being concomitant (non-paralytic). Of these there were 53 convergent squints and 16 divergent squints giving a ratio of about $3: 1$ convergent to divergent squints. The onset of the squints was much earlier than in the general population and why this was so remains largely unknown, but was presumably related to the fact that some $26 \%$ of the children had some severe abnormal event in the perinatal period such as fetal distress and birth asphyxia. Most of the squints had a recorded onset during the first six months of life and most of these were noticed straight after birth (table III).

Nystagmus was noticed in 11 children, and the type of nystagmus varied. Horizontal pendular nystagmus occurred in five children, two of whom were mongols. Vertical nystagmus was present in only two children, in one case probably due to bartiturate therapy. Latent nystagmus was present in three children, all of whom had convergent squints, and one child had a combination of rotatory nystagmus and myopia.

Cataracts were found in five children, of whom two had the rubella syndrome with unilateral microphthalmos, retinopathy, and convergent squints associated with the cataracts. Congenital posterior polar cataracts were present in two children and one mongol boy had punctate cataracts large enough to affect vision.

Microphthalmos in five children was in each case unilateral and associated with other ocular abnormalities-namely, rubella cataracts and retinopathy, toxoplasmosis retinopathy, retrolental fibroplasia, and persistent hyperplastic primary vitreous.

The rubella syndrome (two children), toxoplasmosis (one child), retrolental fibroplasia (one child), and "battering" (one child) were responsible for the retinopathies in five children.

TABLE I-General Presenting Features in 171 Children

\begin{tabular}{|c|c|c|c|c|c|}
\hline & & & & No. of Children & $\%$ \\
\hline 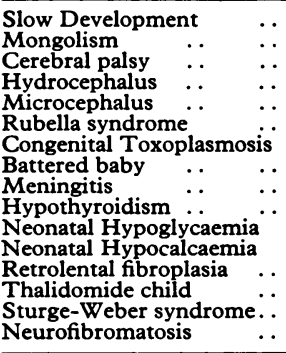 & $\begin{array}{l}\cdots \\
\cdots \\
\cdots \\
\cdots \\
\cdots \\
\cdots \\
\cdots \\
\cdots \\
\cdots \\
\cdots \\
\cdots\end{array}$ & $\begin{array}{l}\cdots \\
\because \\
\because \\
\because \\
\because \\
\because \\
\because \\
\because \\
\cdots \\
\cdots\end{array}$ & $\begin{array}{l}\ldots \\
\cdots \\
\ldots \\
\cdots \\
\cdots \\
\cdots \\
\cdots \\
\cdots \\
\cdots \\
\cdots \\
\cdots\end{array}$ & $\begin{array}{r}110 \\
20 \\
17 \\
8 \\
2 \\
2 \\
2 \\
2 \\
1 \\
1 \\
1 \\
1 \\
1 \\
1 \\
1 \\
1\end{array}$ & $\begin{array}{r}64 \\
12 \\
10 \\
5\end{array}$ \\
\hline \multicolumn{4}{|c|}{ Total } & 171 & 100 \\
\hline
\end{tabular}

TABLE II-Summary of Ocular Findings in 171 Mentally Handicapped Children

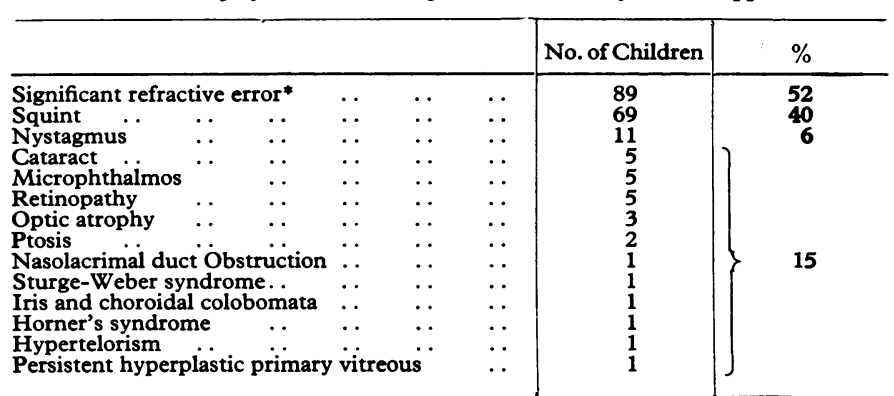

Significant refractive error: $>+1.50 \mathrm{D}$ sphere; $>-0.75 \mathrm{D}$ sphere; $> \pm 0.75$ D cylinder.

TABLE III-Age of Onset of Squint in 60 Mentally Handicapped Children*

\begin{tabular}{|c|c|c|c|c|c|c|c|c|c|c|c|c|c|c|c|}
\hline $\begin{array}{l}\text { Age of onset (Months) } \\
\text { No. of children }\end{array}$ & $\frac{-2}{28}$ & $\begin{array}{c}-4 \\
5\end{array}$ & -6 & $\begin{array}{c}-8 \\
4\end{array}$ & $-\frac{-10}{3}$ & -12 & -14 & -16 & $\begin{array}{c}-18 \\
0\end{array}$ & -20 & -22 & $\begin{array}{c}-24 \\
0\end{array}$ & $\begin{array}{c}-26 \\
1\end{array}$ & -28 & $\begin{array}{c}-30 \\
1\end{array}$ \\
\hline
\end{tabular}

*Age of onset in the remaining nine children with squints occurred from 32-54 months. 
Other fundus abnormalities were optic atrophy of various causes (hydrocephalus and "battering") and choroidal colobomas.

Miscellaneous conditions affecting the ocular adnexae were ptosis (two cases), persistent nasolacrimal duct obstruction, hypertelorism, and Horner's syndrome. There was one boy with persistent hyperplastic primary vitreous previously mentioned in association with microphthalmos.

\section{Discussion}

In this group of 171 children the high incidence of ocular abnormalities does indicate that all such developmentally handicapped children should have routine ophthalmic and orthoptic examinations. Some authors have found certain ocular abnormalities in other groups of handicapped children, such as those with cerebral palsy. Breakey (1955) found an incidence of "ocular muscle imbalance" of $48 \%$, Douglas (1961) an incidence of $37 \%$ of squint, and Fantl and Perlstein (1961) a higher degree of hypermetropia. Mongols and other mentally handicapped children were found to have an incidence of squint of $25 \%$ by Gardiner (1967), and Bankes (1972) noted that most squints in mentally handicapped children had an onset at birth or just afterwards. Venables (1967) also reported a high incidence of squint in "minimally handicapped children" varying from $37 \%$ in "clumsy" children to $54 \%$ in "problem children." More recently Edwards et al. (1972) have shown the value of the ophthalmic examination as part of the evaluation of suspected mentally handicapped children. The evidence they put forward for the routine ophthalmic examination was that the ocular defects of many of these children would have otherwise gone unrecognized and untreated.

Ideally, the routine ophthalmic examination should be carried out in an assessment centre where the whole assessment is geared to the needs of these children, and it is hoped that purpose-built centres will one day be available in all parts of the country.
It has been argued that early detection of ocular defects contributes little to the developmentally handicapped child, but we think that the earlier and better the visual sense functions then the greater the chance the child has of achieving his potential. Particular regard was paid to the visual function of the children by the assessment centre team, and more detailed visual function tests, in relation to other senses, were carried out as part of the Griffiths Mental Development Scale tests. This was in addition to the more formal estimation of vision when this was possible. Reassurance of parents that their child had normal vision and healthy eyes removed a great deal of worry, and sensible discussion and explanation about children with ocular abnormalities went a long way in helping parents to accept a mentally and visually handicapped child. Such advice and reassurance, however, can be given only when the developmentally handicapped child has received full ophthalmic and orthoptic examinations.

This work was possible only with the support and encouragement of the assessment centre team at St. Mary's Hospital (Dr. P. Cox, the late Dr. Alexander, Mr. R. Marsh, Mr. A. Richards, Miss E. L. Rowse, and Miss Woods) and to them go our considerable thanks. Miss R. Offer provided the secretarial help, and we wish to thank her for this.

\section{References \\ Bankes, J. L. K., Thornhill, D. M., Rowse, E. L., and Corr, P. E. (1972). In Orthoptics, Ed. J. Mein, p. 333. Amsterdam, Excerpta Medica. Breakley, A. S. (1955). Archives of Ophthalmology, 53, 852. Douglas, A. A. (1961). In Cerebral Palsy in Childhood and Adolescence, \\ Edwards, W. C., Price, W. D., and Weiskopf, B. (1972). Fournal of Pediatric Ophthalmology, 9, 162. \\ Fantl, E. W., and Perlstein, M. A. (1961). American fournal of Diseases of Children, 102, 36. \\ Gardiner, P. A. (1967). British fournal of Ophthalmology, 51, 469. \\ Griffiths, R. (1954). The Abilities of Babies. London, University of London Press. \\ Stanworth, A. (1969). Strabismus'69. Transactions of the Consilium Europeaum Strabismi Studio Deditum Congress, p. 73. London, Henry Kimpton. \\ Venables, W. A. (1967). British Orthoptic fournal, 24, 53.}

\section{PRELIMINARY COMMUNICATIONS}

\section{Urinary Excretion of Fibrinogen- related Materials, Complement, and Immunoglobulins in Proliferative Glomerulonephritis and after Renal Transplantation}

\author{
M. S. HOQ, J. L. ANDERTON, M. CUNNINGHAM,
} JOHN D. CASH

British Medical fournal, 1974, 2, 535-538

\section{Summary}

Using a radial immunodiffusion technique we measured the urinary concentration of material related to complement (C3), IgM, and IgG along with fibrin-fibrinogen degradation

South-east Scotland Regional Blood Transfusion Centre, Royal Infirmary, Edinburgh EH3 9HB

M. S. HOQ, M.B., PH.D., Research Fellow

M. CUNNINGHAM, M.R.C.O.G., Registrar

JOHN D. CASH, PH.D., F.R.C.P., Director

Nuffield Transplant Unit, Western General Hospital, and Medical Renal Unit, Royal Infirmary, Edinburgh

J. L. ANDERTON, P.R.C.P., Consultant Physician products and heterophile (sheep) haemagglutinins in 15 patients with proliferative glomerulonephritis and in 10 patients after renal transplantation. There was a significant correlation between all variables measured, and serial studies showed that with the exception of IgG-related materials potentially useful information could be obtained on the detection of rejection and the response to treatment in both conditions. The significance of these observations is discussed.

\section{Introduction}

Histological evidence now suffices to show that in active proliferative glomerulonephritis and during renal homograft rejection fibrinogen-related material, complement (C3), and immunoglobulins may be deposited within the glomerulus (Lachmann et al., 1962; Koffler and Paronetto, 1965; Paronetto and Koffler, 1965; Hadley and Rosenau, 1967; Porter et al., 1968; Herdman et al., 1970; Davison et al., 1973). More recent studies have shown that at least one aspect of these intrarenal events (fibrin deposition) can be monitored in individual patients by the quantification of the urinary fibrin-fibrinogen degradation products (F.D.P.; Clarkson et al., 1970; Clarkson et al., 1971; Davison et al., 1973). Other studies have suggested that the overall intrarenal inflammatory reaction in these conditions can also be followed by 